\author{
3. Ю. Петрова \\ Институт русского языка им. В. В. Виноградова РАН \\ (Россия, Москва) \\ zoyap@mail.ru
}

\title{
ОККАЗИОНАЛИЗМЫ КАК ЭЛЕМЕНТЫ ОБРАЗНЫХ ПАРАЛЛЕЛЕЙ В ЯЗЫКЕ ХУДОЖЕСТВЕННОЙ ЛИТЕРАТУРЫ
}

В статье рассматриваются различные типы окказиональных слов, включенных в пять выпусков «Материалов к словарю метафор и сравнений русской литературы XIX-XX вв.» («Птицы», «Звери, насекомые, рыбы, змеи», «Растения», «Камни, металлы», «Ткани, изделия из тканей»), и их роль в развитии семантических классов метафор и сравнений. Среди окказионализмов выделяются слова, образованные по высокопродуктивным словообразовательным моделям. Их новизна ощущается довольно слабо, и фиксируются они в языке художественной литературы с начала исследуемого периода - с XIX в.: существительные на -ость / -есть, образуемые от метафорических прилагательных, в свою очередь производных от названий животных, растений, камней и металлов, тканей, например: медведь - медвежий медвежесть, лилия - лилейный - лилейность, камень - каменный - каменность и т. д.; наречия на -о, также образуемые от производных метафорических прилагательных.

По некоторым другим моделям образуются слова с более высоким показателем окказиональности. Они появляются в языке художественной литературы в XX в. Это такие типы окказионализмов, как существительные женского рода с нулевым суффиксом от метафорических существительных или прилагательных, например: изумрудь, бирюзовь, серебрь; глаголы с суффиксами -u(mb) и e-(mь) (иногда с постфиксом -ся) со значением сходства, образованные от существительных, например: орлить, имелить, сливеть, хризантемиться, черносливиться, кружеветь, бирюзиться и др.; глаголы с приставками раз- из-, o-, вы- и суффиксом -u(mb): размедведить, расканареить, разбукетиться, испавлиниться, олебедить, очугунеть, вьзмеить и др.

Кроме того, в исследованном материале встречаются индивидуально-авторские окказионализмы, не соответствующие никаким словообразовательным моделям, например, у А. Белого: жизнь - волковня, облака - бархатаны, персикань, человек - быкан, улица - алмазник, глаза - бирюзники. Все эти индивидуальные 
окказионализмы всё же вписываются в определенные образные параллели: люди волки, облака - бархатные, персиковые, человек-бык, свет - алмаз, глаза - бирюза.

Отдельную группу окказионализмов составляют сложные слова.

Проведенное исследование позволяет сделать вывод, что окказиональные дериваты составляют большой процент элементов образных параллелей в языке художественной литературы и играют важную роль в их варьировании, развитии и обновлении.

Ключевые слова: метафора, сравнение, образная параллель, словообразование, окказионализм, язык художественной литературы, эволюция.

Образная параллель определяется как совокупность метафор и сравнений (компаративных тропов), в основе которых лежит семантический инвариант - пара семантических категорий, к которым относятся опорные слова тропов (образы сравнения и предметы сравнения), например, <медведь, человек>, <васильки, глаза>, <бирюза, небо > и т.д. Формальное выражение таких семантических инвариантов при реализации их в тексте художественного произведения варьируется. Это варьирование происходит, с одной стороны, за счет различных синтаксических конструкций, основные из которых - метафора и сравнение. С другой стороны, варьирование состава образных параллелей может быть связано с разными типами самих опорных слов, представляющих образы сравнения тропов, с точки зрения непроизводности / производности. Основные, ядерные слова, реализующие определенный семантический тропеический инвариант, относятся к непроизводным: зверь, медведь, птица, павлин, крылья, цзветок, лилия, камень, железо и пр. Большой процент элементов каждой образной параллели составляют дериваты, возможность образования которых по определенным моделям (более или менее продуктивным) является в то же время и возможностью пополнения и развития образных параллелей.

Описание эволюции образных параллелей, развития семантических классов компаративных тропов за счет включения в них ранее не задействованных в тропах лексических единиц, связанных определенными системно-языковыми отношениями со словами, традиционно включавшимися в тропы, является одной из основных задач многотомного лексикографического проекта «Материалы к словарю метафор и сравнений русской литературы XIX-XX вв.» [Кожевникова, Петрова 2000-2017]. Роль словообразовательной мотивации в образных полях на материале пяти выпусков этого словаря: «Птицы», «Звери, насекомые, рыбы, змеи», «Растения», «Камни, минералы» и «Ткани, изделия из тканей» — рассмотрена в работе [Петрова 2015].

Среди дериватов, пополняющих семантические классы тропов, варьирующих выражение смысловых инвариантов, лежащих в их основе, особая роль принадлежит словообразовательным неологизмам, окказиональным образованиям, которые по самой своей природе призваны придать новую форму выражения традиционному компаративному соответствию. Рассмотрим основные типы таких 
окказионализмов, основываясь на данных вышеупомянутого словаря. Ряд словообразовательных моделей имеют варианты со значением подобия, для которых характерно расширение возможностей образования новых элементов за счет окказионализмов в языке художественной литературы.

Метафорические прилагательные, производные от названий животных, растений, камней и металлов, тканей: зверинылй, собачий, птичий, змеиный, жабий, малиновылй, персиковыци, каменный, железный, бирюзовый, бархатный — дают начало двум продуктивным словообразовательным моделям, по которым создаются окказионализмы:

1. Существительные на -ость (-есть) [Виноградова 2012: 223], которые образуются от прилагательных всех рассматриваемых классов компаративных тропов: куриность, звериность, медвежесть, львиность, тигриность, лилейность, персиковость, черносливность, ландышевость, тюльпанность, тростниковость, каменность, мраморность, антрацитовость, железность, стальность, свинцовость, янтарность, жемчужность, изумрудность, опаловость, бархатность и т. д. Такие существительные фиксируются в литературе начиная с XIX в.: «Действует ли так сырой климат Петербурга, или скрываются другие, более сложные причины, но вы заметили, вероятно, что в большинстве петербургских жителей присутствует что-то разварное и раскислое, преобладает какая-то расслабленность и черносливность, хотя тут же надо сказать - и вы, вероятно, также это заметили - свойства эти нисколько не мешают служить с успехом и приносить пользу себе и отечеству» (Григорович 1845), «В обнаженных плечах и руках Кити чувствовала холодную мраморность, чувство, которое она особенно любила» (Л. Толстой 1878), они распространены и в XX в.: «Типические черты Гоголевских персонажей связаны с особенностями усадьбы; вещей, всего уклада: грубость и медвежесть Собакевича, сахарная мечтательность Манилова, «историчность» Ноздрева, скопидомство Коробочки < .. > - родились и развились благодаря поместной, крепостной собственности и быту, на ее почве возникшему» (Александр Воронский. Гоголь, 1934), «Странно, что он нравился Сталину. Как не похожа эта тигриность на привычные взору вождя непропеченные блины» (Нагибин 1994), «Я с восхищением смотрю на его постоянную выпрямку и в его лицо: откуда такая самозабывчивая железность, когда сама жизнь будто не дорога?» (Солженицын 1998).

От метафорических прилагательных образуются и другие существительные со значением отвлеченного признака, опосредованно мотивированные исходными существительными, круг которых гораздо более ограничен. С суффиксом -cmв(o) из всех рассматриваемых классов образуют дериваты только названия животных. Этот класс содержит ряд узуальных элементов: зверство, свинство, обезьянство, попугайство, окказионализмы из художественных текстов пополняют его: медвежество: «Кокосов пеанами и кохерами неожиданно ловко для его медвежества зажимал кровоточащие сосуды» (Пильняк 1926).

2. Наречия на -о [Виноградова 2012: 219]. Они, как и существительные на -ость, тоже характерны для всех рассматриваемых семантических классов. Сочетания 
таких наречий с глаголами чаще всего синонимичны сравнительным конструкциям, в которых исходное мотивирующее существительное является образом сравнения, а глагол - признаком сравнения. Сравнительные конструкции представляют традиционное выражение компаративного отношения, конструкции с наречием обновляют его: «<..> баранно проблеяли смехом» (Белый 1921) - ср. проблеять, как бараны; «Девчонка часто и нервно смеялась, щеки клюквенно налились, и белки глаз зарозовели» (В. Личутин 1977) - ср. налиться, как клюква; «Москва на то и мегаполис, что ее коммуникационная сеть коврово тянется на много квадратных километров» (В. Черкасов 2000) - ср. тянуться, как ковер.

Наречия со значением сравнения могут сочетаться и с прилагательными; такие конструкции тоже синонимичны сравнительным, роль признака сравнения в них выполняет прилагательное: «<..> - думала княгиня, заложив под голову свои алебастрово бледные, хорошо выточенные руки и слегка улыбаясь самой спокойной, чтоб не сказать равнодушной, улыбкой» (В.В. Крестовский 1867), «Лизанька сидела строгая, отчужденная, с картофельно бледным лицом, под цвет больничной застиранной рубахи» (В. Личутин 1987).

Очень часто на основе таких сочетаний образуются сложные прилагательные, в которых сохраняется это отношение частей: первая часть - образ сравнения, вторая — признак: «Какие-то мылиино-юркие, в платках женщины» (Замятин 1913) ср. юркие, как мыши; «он - приват-доцент, с жаждою адвокатской карьеры, белесый, баранно-тупой, не имеющий собственных слов» (Белый 1930) — ср. тупой, как баран; «Зимою же, когда могильный курган - в горностаевой мантии снега, каждый день в голубино-сизых предрассветных сумерках выходит на вершину его старый сиводуший лисовин» (Шолохов 1932), «Афоня-кузнец, должно, за все лето перенимавший рубахи, курино-бельй, пупырчатый от речной остуды, молча обвел взглядом ту сторону» (Е. Носов 1977).

Иногда отношение частей несколько другое: в роли образа сравнения выступает некоторая часть, принадлежность того, что обозначено исходным существительным: зверино крепкие зубы - крепкие, как у зверя, ястребино-скрюченные корни - скрюченные, как когти ястреба, петушино-яркий плавник - яркий, как хвост петуха: «Похотливое храпение обнажало их белые, зверино крепкие зубы» (Ф. Сологуб 1905), «Зыбкий свет костра высвечивает корни старого дерева, обнаженные, ястребино-скрюченные, цепко обхватившие валуны» (Е. Носов 1970), «Так никому и не покорившейся, надменной, величаво скорбной - вот какой она выглядела, только брюхо < ..> выдавало слабость, даже беспомощность рыбы, сам же плавничок был все еще петушино-яркий, но казался уже лишним на этом холодном, сером теле» (В. Астафьев 1968-1991).

Те же метафорические первые элементы могут образовывать сложные прилагательные, в которых отношение между частями другое; это отношение объединения признаков, аналогичное отношению сочинения: лилейно-легкие персты 'лилейные и легкие', каменно-серьезное лицо 'каменное и серьезное', жемчужно-ровные зубы 'жемчужные и ровные', изумрудно-золотая листва 'изумрудная и золотая', хрустально-голубое море 'хрустальное и голубое' и т.п.: «Лилейно-легкими перстами 
Лелеет грудь Земли Апрель» (Тиняков 1909), «От этого Тимуру, кажется, полегчало, потому что, вцепившись в подлокотники, поджав ноги и не раскрывая глаз, он с каменно-серьезным лицом проделал еще несколько плавных кругов» (Евгений Чижов 2012).

Указанные выше слова образуются по высокопродуктивным словообразовательным моделям, их новизна ощущается довольно слабо. По некоторым другим моделям образуются слова с более высоким показателем окказиональности. Они появляются в языке художественной литературы в ХХ в. Это, например, существительные женского рода с нулевым суффиксом от метафорических существительных или прилагательных (такие существительные без подразделения на образованные от прямых / метафорических значений мотивирующих слов рассматриваются в работах [Александрова 1980: 95; Виноградова 2012: 231-234]). В нашем материале встретились только дериваты, образованные от названий камней и металлов: изумрудь, серебрь, бирюзовь:

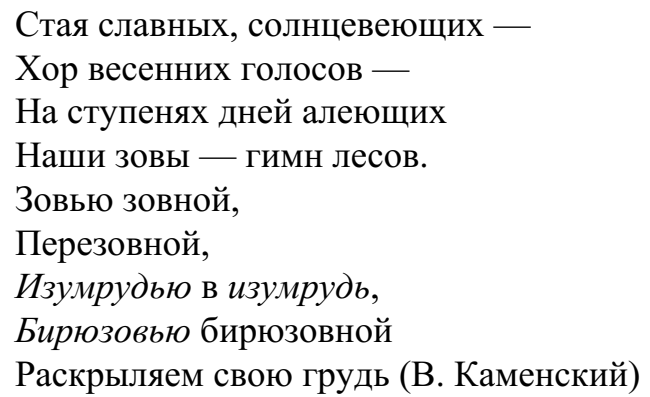

(ср. традиционное выражение тропов - изумрудный лес, изумрудные кусты, деревья; бирюза неба, бирюзовое небо), и так остро раскраивался мрак Багровой серебрью нервных молний (Сельвинский) (ср. серебряная молния: Его безумные очи слепила серебряная молния. Бледнокаменное лицо полыхало и мерцало от внезапных вспышек и взрывов... (Белый 1917)).

Надо отметить также глаголы с суффиксами $-u(m b)$ и $e$ - $(m b)$ (иногда с постфиксом -ся) со значением сходства, образованные от существительных [Александрова 1980: 100-107; [Виноградова 2012: 241-245]; в этих группах есть некоторое количество узуальных глаголов, фиксируемых словарями: козлить, лисить, свинячить, ишачить, петушиться, собачиться, бычиться, ежиться, змеиться, звереть, советь, каменеть, деревенеть, жаргонные глаголы крысить, ослить, ср. также жаргонный быковать с другим суффиксом, -оват(b). Значительно больше среди таких производных глаголов окказионализмов, образующихся по той же модели, но от таких основ, от которых узуальные глаголы не образуются: орлить, крылить, стрекозить, имелить, пчелить, астрить, сливеть, клюквиться, хризантемиться, черносливиться, вуалить, вуалиться, кружеветь, кружевиться, бирюзеть, бирюзиться, изумрудить, алмазить, алмазиться, бриллиантиться, жемчужиться, хрусталеть, янтареть, янтариться, чугунеть, чугуниться, ср. глагол свинцоветь от прилагательного и др. Все эти глаголы развивают традиционные тропеические 
соответствия в рассматриваемых семантических классах тропов: «Океан как будто лелеет эти островки: он играет с берегами, то ревет, сердится, то ласково обнимает любимцев со всех сторон, жемчужится, кипит у берегов и приносит блестящую раковину, или морского ежа, или красивый, выработанный им коралл, как будто игрушки для детей» (Гончаров 1855), «Луна алмазит стекла, Прохладный свет лия» (Белый 1908), «Но вот, / чугунясь загаром плеча, <.. > фигура чья-то / над книгою» (Асеев 1925), «Шмелит-пчелит виолончель» (Северянин), «Над лебедемЕгорьем Орлит аэроплан» (Клюев 1926).

Ряд окказиональных глаголов со значением подобия образуется по словообразовательной модели с приставками раз-, из-, o-, вbl- и суффиксом -u(mb) [Александрова 1980: 108-112] (надо отметить, что по этой модели образуются и узуальные глаголы со значением подобия: распетушиться и вспетушиться): размедведить, раскрылить, раскрыляться, расканареить, расканареиваться, распавлинить, разбукетиться, разалмазиться, испавлиниться, олебедить, обрильянтить, ожелезить, ожелезиться, очугунеть, освинцоветь, вьзммеить и др., например: «Разбукетилось небо к вечеру» (Кузмин 1917) (ср. закат - букет: Прозрачный, розовый букет (То поздний заревой отсвет) Расцвел на шпице колокольни (Ф. Глинка 1830-1849)), «Вчера человек - / единым махом / клыками свой размедведил вид я! / Косматый. / Шерстью свисает рубаха» (Маяковский 1923) (ср. человек - медведь), «Раскройте вы книгу мою, Раскрыльте ее для полета!» (Луконин 1959) (ср. книжные листы - крылья).

Есть несколько образований с приставкой вз- (воз-): взорлить, вскрылить: «Я покорил Литературу, Взорлил, гремящий, на престол!» (Северянин 1912) (ср. поэт - орел), «Ветер морской Паруса вскрылил» (Каменский 1928) (ср. паруса крылья), воскрылять: «восторг воскрыля» (Маяковский 1923), «Дух воскрыляю свой в небо» (Северянин 1925) (ср. крылья духа), воскрылиться: «И да воскрылится в зените Моя всезрящая душа!» (Тряпкин 1969).

В исследованном материале встречаются индивидуально-авторские окказионализмы, не соответствующие никаким словообразовательным моделям, например, у А. Белого: жизнь - волковня: «подошел - прошепнуть, озираясь испуганно, ей предложение гнусное: волк; мы по жизни проходим волками, и жизнь есть волковня (пора бы, пора ее - к чорту!)» (1926). Слово волковня есть в Словаре Даля (о соотношении окказионализмов А. Белого и Словаря Даля пишет Н. А. Кожевникова [1992: 156-173]) со значением 'волчья яма', но в тексте Белого, видимо, значение другое, близкое к отглагольным существительным со значением процессуального признака типа беготня, толкотня, мотовня;

облака - бархатаны, персикань: «Тогда: -

- небеса просветятся таким аксамитово-синим; взлетят облака бархатаны; -

- совсем персиканы! !» (1921);

человек - быкан: «Папа встанет, качнется с натуги, посмотрит; и что-то захочет сказать: не сумеет - мымыкает, грустный быкан (1921),

улица - алмазник: «Не улица - ясный алмазник! А угол - букет из цветов. Здесь просинилось - ртутными светами; там — взрозовело, подпыхнуло - ярче, все жарче» (1926), 
глаза - бирюзники: «Под очками сверкнут два бирюзника: папины глазки; заплачет он» (1921).

Все эти индивидуальные окказионализмы вписываются в определенные образные параллели: люди - волки, облака - бархатные, персиковые, человек - бык, свет - алмаз, глаза - бирюза.

Большую группу окказионализмов, обновляющих традиционные образные параллели, представляют сложные слова. В большинстве случаев варьирование устойчивых образных соответствий происходит в сложных прилагательных. Некоторые из них, мотивированные метафорическими прилагательными, мы уже рассмотрели выше.

Отношения между частями сложного прилагательного и между ним и определяемым существительным могут быть разными. Первая часть прилагательного может быть определением второй, конкретизируя ее [Виноградова 2012: 211]; такие сложные прилагательные, соответственно, конкретизируют метафору, выраженную исходным производящим словом. Так, образ крылья души, крылатая душа варьируется тропами огнекрылая душа (Клюев), многокрылая душа (Ремизов), теплокрылая душа (Ивнев), крылья вдохновения, крылатое вдохновенье иирокрылье вдохновенья (Тютчев), крылья мечты, грезы, крылатая мечта, греза - легкокрылое мечтанье (Пушкин, Языков), легкокрылые грезы (Баратынский), златокрылая мечта (Тютчев), золотокрылая мечта (Ростопчина), быстрокрылые мечты (Фофанов), среброкрылая греза (Брюсов), стокрылая греза (Брюсов), крылья сна, крылатый сон - легкокрылый сон (Батюшков), пестрокрылый сон (Гумилев), белокрылый сон (Клюев), крылья ветра - теплокрылый ветер (Бенедиктов), тихокрылый ветер (Городецкий), буйнокрылые вихри (Клюев), грива реки, водопада-белогривый водопад (Ахматова), золотогривая река (Окуджава) и т. д.

Части сложного прилагательного могут быть связаны отношением сравнения [Виноградова 2012: 213-214]: змеевласые старцы (А. Белый) ('с волосами, как змеи'), крылоглазая (Шершеневич) ('с глазами, как крылья’), розоустая (С. Соловьев) ('с устами, как розы') и т.д.

Отношения могут быть более сложными: между частями сложного прилагательного существует отношение принадлежности, между прилагательным и определяемым им существительным - отношение подобия и носителя признака. Например, прилагательное орлоносый: «<..> крещение с никогда не виденными черными кудрявыми орлоносыми голыми людьми и детьми...» (Цветаева) - синонимично сочетаниям «с орлиным носом», «с носом, как у орла»; вороногорлая: Как чума во мне Жаркая любовница <..> Незастегнутый корсаж, Сама вороногорлая (Сельвинский) - синонимично сочетаниям «с вороньим горлом», «с горлом, как у вороны», гусинолапый клен (Северянин) - синонимично сочетанию «как бы с гусиными лапами».

Иногда между таким прилагательным и определяемым существительным имеется только значение подобия, без значения носителя признака: совиноглазые окна $($ Замятин $)=$ 'окна, как совиные глаза', фазаньехвостые восходы (Третьяков) = 'восходы, как фазаньи хвосты'. 
Изредка встречаются сложные существительные, выражающие отношение подобия: песнокрылие: «Я песнокрылия лишился» (Клюев 1911) (ср. песня - крылья, крылатая песня), автостадо, автомышь: «Автостадо гремит; и глотает свой кислород, / схожий с локтем на вкус, углекислый рот» (Бродский 1974), «Автомышь светом фар толчею колонн / сводит вдали с ума, как слонов Ганнибала» (Бродский 1992) (ср. автомобиль - мылшь, стадо автомобилей). Иногда первая часть сложного существительного - образа сравнения тропа — является определением второй (как в сложных прилагательных типа белокрыльй (сон)): белолилия: «И облако - как белолилия» (Северянин), алоивет: «А она [Москва] алоияетом возмездья Из рабочего пота взошла» (Городецкий).

Широкое распространение в современной поэзии сложных слов со значением компаративных тропов отмечается в работе Н.А. Николиной [2009: 96-97], приводятся примеры птице-ребенок, человекоцветок и пр. По мнению Н.А. Николиной, «интенсивное использование сложных слов, свертывающих ту или иную образную параллель, отражает синтетизм современного поэтического мышления». Окказиональные композиты включают случаи «наложения основ»: неврастение: «Вечнозеленое неврастение, слыша жжу / це-це будущего, я дрожу, / вцепившись ногтями в свои коренья» (Бродский 1977) (неврастения + растение), в основе лежит взаимодействие семантических категорий <растение, человек>. Еще один пример не столь явного наложения основ: сложное слово муу-танки: «На закате ревут, возвращаясь с полей, муу-танки, / крупный единорогий скот» (Бродский 1988). Окказионализм варьирует семантический инвариант <крупный рогатый скот, танки> и в то же время созвучен слову мутанты.

Благодаря описанным выше случаям создания окказиональных слов создаются разнообразные возможности варьирования, обновления традиционных образных параллелей, которые могут выражаться словами разных частей речи, разной морфемной структуры. Например, смысловой инвариант <змеи, волосы> выражается как узуальными элементами змея, змеи: «И груди белые, как снег, И черными на них рассыпалась змеями Великолепная коса!» (Языков 1844), глаголом змеиться: «Змеились косы на плечах младых» (Лермонтов 1832), прилагательными змеистые: «Две змеистые косы, струясь, бежали с узких плеч на стройную выгнутую спину» (Б. Садовской), змеиные: «И встречаю тебя у порога - С буйным ветром в змеиных кудрях» (Блок 1907), так и окказиональными наречиями: «Кудри черные змейно трепал ветерок» (Есенин 1910), «И пепельных волос волна, упав на плечи, Змеино поднялась к тяжелой голове» (Бальмонт), сложными словами разной структуры: «Бог кивнул мне, смуглоликий, Змеекудрой головой» (Вяч. Иванов 1912), «И вновь, сверкнув из чаши винной, Ты поселила в сердце страх Своей улыбкою невинной В тяжелозмейных волосах» (Блок 1906). Выражение смыслового инварианта <змея, улыбка> (традиционно змея, змеиться) варьируется окказионализмами змийность: «Змийность уст у женщин Леонардо» (Волошин 1910), вьзмеить: «Пусть ропщут поэты, / слюною плеща, / губою / презрение вызмеив» (Маяковский 1929).

Проведенное исследование позволяет сделать вывод, что окказиональные дериваты составляют большой процент элементов образных параллелей в языке художественной литературы и играют важную роль в их варьировании, развитии и обновлении. 


\section{Литература}

Александрова О.И. Русское поэтическое словотворчество: организация плана выражения // Художественная речь. Традиции и новаторство. Куйбышев, КГПИ, 1980. C. 91-142.

Виноградова В.Н. Система русского словообразования в функционально-стилистическом аспекте. М.: ООО «Инфотех», 2012. 336 с.

Кожевникова Н.А. Язык Андрея Белого. М.: Институт русского языка РАН, 1992. $255 \mathrm{c}$.

Кожевникова Н.А., Петрова З. Ю. Материалы к словарю метафор и сравнений русской литературы XIX-XX вв. Вып. 1. «Птицы». М.: Языки русской культуры, 2000. 480 с.; Вып. 2. «Звери, насекомые, рыбы, змеи». М.: Языки славянских культур, 2010. 512 с.; Вып. 3. «Растения». М.: Языки славянской культуры, 2015. 448 с.; Вып. 4. «Камни, металлы»; Вып. 5. «Ткани, изделия из тканей». М.: Издательский дом ЯСК, 2017680 c.

Николина Н. А. Активные процессы в языке современной русской художественной литературы. М.: ГНОЗИС, 2009. 336 с.

Петрова 3. Ю. Роль словообразования в развитии образных параллелей в языке художественной литературы // Осмь десять: Сборник научных статей к 80-летию И. С. Улуханова. М.: Издательский центр «Азбуковник», 2015. С. 155-174.

Русская грамматика: научные труды / Российская академия наук. Институт русского языка им. В. В. Виноградова (репринтное издание). М., 2005. Т. 1. 1496 с.

\section{Z. Yu. Petrova}

V.V. Vinogradov Russian Language Institute of the Russian Academy of Sciences (Russia, Moscow)

zoyap@mail.ru

\section{OCCASIONALISMS AS ELEMENTS OF FIGURATIVE PARALLELS IN THE LANGUAGE OF LITERATURE}

The article considers different types of occasional words included in five issues of «Materials to the dictionary of metaphors and similes of the XIX-XX centuries Russian literature» («Birds», «Animals, insects, fish, snakes», «Plants», «Stones, metals», «Fabrics»), and their role in the evolution of semantic classes of metaphors and similes. Among the occasionalisms, words formed by highly productive word-formation models are distinguished, their novelty is felt rather faintly, and they are fixed in the language of literature from the beginning of the period under study - from the XIX century: nouns with suffixes -ost' / -est' formed from metaphorical adjectives, derived from the names of animals, plants, stones and metals, fabrics; adverbs ending in - $o$, also formed from metaphorical adjectives. 
For some other models, words with a higher occasionality rate are formed. They appear in the language of literature in the twentieth century. These are feminine nouns with a zero suffix derived from metaphorical nouns or adjectives, verbs with the suffixes $-i t$ ' and -et' (sometimes with a postfix -sya) with the meaning of similarity derived from nouns, verbs with prefix $r a z-, i z, o-, v y$ - and the suffix -it'.

In addition, individual author's occasionalisms are found in the studied material, which do not meet any derivational models. All these individual occasionalisms still fit into certain figurative parallels.

A separate group of occasionalisms are compound words.

The conducted research allows to conclude that the occasional derivatives make up a large percentage of the elements of figurative parallels in the language of literature and play an important role in their variation, development and renovation.

Key words: metaphor, simile, figurative parallel, word formation, occasionalism, language of literature, evolution.

\section{References}

Aleksandrova O. I. [Russian poetic word creation: organization of expression plane]. Khudozhestvennaya rech'. Traditsii i novatorstvo [Language of literature. Traditions and innovativeness]. Kuibyshev, Kuibyshev State Pedagogical Institute, 1980, pp. 91-142. (In Russ.)

Vinogradova V.N. Sistema russkogo slovoobrazovaniya v funktsional'no-stilisticheskom aspekte [Russian word-formation system in functional-stylistic aspect]. Moscow, OOO «Infotekh» Publ., 2012. 336 p.

Kozhevnikova N. A. Yazyk Andreya Belogo [The language of Andrei Bely]. Moscow, Russian Language Institute, Russian Academy of Sciences, 1992. 255 p.

Kozhevnikova N.A., Petrova Z. Yu. Materialy $k$ slovaryu metafor $i$ sravnenii russkoi literatury XIX-XX vv. Vyp. 1: «Ptitsy» [Materials for the dictionary of metaphors and similes of the XIX-XX centuries Russian literature. No. 1. «Birds»]. Moscow,: Yazyki Russkoi Kul'tury Publ., 2000. 480 p.; Vyp. 2. «Zveri, nasekomye, ryby, zmei» [No. 2. «Animals, insects, fish, snakes»]. Moscow, Yazyki Slavyanskikh Kul'tur Publ., 2010. 512 p.; Vyp. 3. «Rasteniya» [No. 3. «Plants»]. Moscow, Yazyki Slavyanskoi Kul'tury Publ., 2015. 448 p.; Vyp. 4. «Kamni, metally»; Vyp. 5. «Tkani, izdeliya iz tkanei» [No. 4. «Stones, metals»; No. 5. «Fabrics»]. Moscow, Izdatel'skii Dom YaSK Publ., 2017. 680 p.

Nikolina N. A. Aktivnye protsessy v yazyke sovremennoi russkoi khudozhestvennoi literatury [Active processes in the language of modern Russian fiction]. Moscow, GNOZIS Publ., 2009. 336 p.

Petrova Z. Yu. [The role of word formation in the evolution of figurative parallels in the language of literature]. Osm' desyat': Sbornik nauchnykh statei k 80-letiyu I. S.Ulukhanova. Moscow, Izdatel'skii tsentr «Azbukovnik» Publ., 2015, pp. 155-174. (In Russ.)

Russkaya grammatika [Russian grammar]. Vol. 1 (reprint). Moscow, 2005. 1496 p. 